\title{
Analisis Pendapatan dan Profitabilitas pada Peternakan Sapi Perah Sumber Mulya di Kabupaten Kepahiang
}

The income and profitability analysis of Sumber Mulya dairy farm in Kepahiang regency

\author{
Dadang Suherman $^{1}$, Sutriyono ${ }^{1}$ dan Riko Herdiansah ${ }^{2}$ \\ ${ }^{1)}$ Program Studi Peternakan Fakultas Pertanian Universitas Bengkulu \\ ${ }^{2)}$ Program Studi Peternakan Fakultas Peternakan Universitas Tulang Bawang Lampung \\ Corresponding e-mail: dsuherman@unib.ac.id
}

\begin{abstract}
This study aims to determine the amount of income and profitability achieved by the Sumber Mulya dairy farm. This research was conducted from July 1, 2017 to August 31, 2018 at the Sumber Mulya dairy farm. The material used in this research is Sumber Mulya dairy farm in Kepahiang Regency, Bengkulu province. The method used in this research is the case study method. Primary data obtained through interviews with respondents and recording. Data obtained during the last 12 months regarding technical and financial aspects which include data on production costs, revenue data, income data, data on the amount of milk production, and data on the number of lactating cattle. Secondary data obtained from existing data on the farm. Analysis of the data used is the analysis of income formulas and profitability ratios. The results showed that Sumber Mulya's dairy farm is the net income of Sumber Mulya's dairy farm on average per month of Rp. 5,427,176.91 with an average number of lactating cows 7.00. The production cost incurred per month is Rp. 10,032,823.29. Profitability achieved is 53.79\%, the company is said to be profitable because the profitability value is greater than the bank interest rate of $9.00 \%$.
\end{abstract}

Keywords: Income, Dairy Farming, Profitability, Milk Production

\begin{abstract}
ABSTRAK
Penelitian ini bertujuan untuk mengetahui besarnya pendapatan dan profibilitas yang dicapai peternakan sapi perah Sumber Mulya. Penelitian ini dilaksanakan pada bulan Juli 2017 sampai dengan Agustus 2018 di peternakan sapi perah Sumber Mulya. Materi yang digunakan dalam penelitian ini adalah peternakan sapi perah Sumber Mulya di Kabupaten Kepahiang provinsi Bengkulu. Metode digunakan dalam penelitian ini adalah metode studi kasus. Data primer diperoleh melalui wawancara terhadap responden dan recording. Data diperoleh selama 12 bulan terakhir mengenai aspek teknis dan keuangan yang meliputi data biaya produksi, data penerimaan, data pendapatan, data jumlah produksi susu, dan data jumlah ternak laktasi. Data sekunder diperoleh dari data yang ada di peternakan tersebut. Analisis data yang digunakan yaitu analisis rumus pendapatan dan rasio profitabilitas. Hasil penelitian menunjukkan bahwa peternakan sapi perah Sumber Mulya adalah pendapatan bersih peternakan sapi perah Sumber Mulya rata-rata per bulan sebesar Rp. 5.427.176,91,- dengan jumlah sapi laktasi rata-rata 7,00 ekor. Biaya produksi yang dikeluarkan per bulan sebesar Rp. 10.032.823,29,- Profitabilitas yang dicapai sebesar 53,79\%, perusahaan dikatakan profitable karena nilai profitabilitas lebih besar dari suku bunga bank sebesar 9,00\%.
\end{abstract}

Kata Kunci : Pendapatan, Peternakan Sapi Perah, Profibilitas, Produksi Susu

\section{PENDAHULUAN}

Salah satu usaha peternakan yang dapat memenuhi kebutuhan pangan dan dapat meningkat penciptaan lapangan kerja yaitu usaha peternakan sapi perah. Produksi susu baru dapat memenuhi $30 \%$ permintaan konsumsi susu nasional, sisanya $70 \%$ berasal dari impor. Pasar produk susu berpeluang tumbuh dikarenakan konsumsi susu masyarakat Indonesia masih kecil sekitar 15-16 liter per kapita per tahun, di bawah Negara tetangga seperti Thailand yang sudah mencapai 30 liter per kapita per tahun. Kajian perkiraan jumlah sapi perah di Indonesia sekitar 300.000 ekor (BPS, 2018). 
Kabupaten Kepahiang merupakan salah satu wilayah di provinsi Bengkulu yang cocok untuk pengembangan sapi perah. Secara geografis kabupaten Kepahiang merupakan daerah pegunungan yang memiliki suhu lingkungan dingin $\left(15-24{ }^{0} \mathrm{C}\right)$ dan memiliki kekayaan alam berupa pakan ternak seperti rumput alam, limbah pertanian, dan limbah industri pertanian yang melimpah untuk pengembangan sapi perah. Pengembangan sapi perah di kabupaten Kepahiang dimulai sejak tahun 2008 tepatnya di Gapoktan Sumber Mulya desa Sukasari kecamatan Kabawetan. Sapi perah merupakan komoditi unggulan yang dikembangkan pemerintah daerah di desa Sukasari tepatnya pada peternakan Sumber Mulya. Tujuan pengembangan sapi perah yang diharapkan berkembang baik dan menguntungkan sehingga dapat dijadikan percontohan pada anggota masyarakat lainnya.

Hasil survei menunjukkan bahwa perkembangan populasi dan produksi sapi perah di Sumber Mulya jalan ditempat, dilihat dari produksi susu sapi perah yang dipelihara masih sangat rendah yaitu sebanyak $\pm 8,50$ liter/ekor/hari, rataan biaya untuk memelihara sapi perah laktasi sebesar Rp.60.000/ekor/hari. Biaya pemeliharaan sapi perah laktasi antara lain biaya pakan, pegawai kandang, kawin suntik (IB), obat vaksinasi kesehatan (OVK), dan penanganan susu sejak pasca pemerahan, setiap liter susu sapi perah harganya Rp.5.000,-Rp.6.000, dapat dibayangkan berapa minimnya pendapatan peternakan sapi perah di Sumber Mulya kabupaten Kepahiang provinsi Bengkulu.

Pembangunan sub sektor peternakan sangat penting guna memenuhi permintaan masyarakat akan hasil peternakan khususnya produk pangan hewani. Pendapatan masyarakat semakin meningkat seiring dengan bertambahnya jumlah penduduk dan kesadaran pemenuhan kebutuhan gizi, menyebabkan tingginya permintaan akan hasil-hasil peternakan.

Tujuan utama pada perusahaan peternakan sapi perah adalah untuk memaksimalkan pendapatan dan keuntungan perusahaan. Pendapatan dan keuntungan dapat dicapai perusahaan bila dijalankan dengan manajemen yang baik. Pengembangan usaha akan dapat dicapai bila ditunjang oleh besarnya pendapatan dan keuntungan perusahaan yang ditunjukkan oleh besarnya nilai profitabilitas. Dengan demikian, analisis pendapatan dan profitabilitas perlu dilakukan untuk melihat kemampuan perusahaan dalam meraih keuntungan. Selain itu, perlu pula diketahui faktor-faktor yang mempengaruhi nilai profitabilitas. Usaha peternakan sapi perah merupakan kegiatan yang melandasi pada tujuan komersil dengan ternak sebagai alat produksinya. Produksi susu adalah hasil pemerahan sapi perah, kambing perah, kerbau perah dan unta. (Sudono, 2004). Menurut Hadiwiyoto (1994) susu memiliki berat jenis minimal 1,027 pada temperataur $27,5^{\circ} \mathrm{C}$ dan kadar lemak 2,8\%. Usaha peternakan sapi perah selalu membutuhkan dana untuk membiayai operasi usaha. Pembiayaan digunakan bisa dipenuhi dari pemilik berupa modal sendiri maupun dari pinjaman pihak lain atau hutang (Sutrisno, 2000). Hadiwidjaya dan Lely (2009) mengemukakan bahwa biaya tetap merupakan biaya yang jumlah totalnya tetap dalam kisaran 
volume kegiatan tertentu. Biaya tetap tidak akan berubah selama periode tertentu, sehingga biasanya biaya tetap dihubungkan dengan waktu dan periode. Biaya tidak tetap adalah biaya yang diperlukan untuk membiayai proses produksi, besar kecilnya biaya ini tergantung pada besar kecilnya jumlah produksi (Rasyaf, 1996). Biaya tidak tetap terdiri dari biaya bahan baku, biaya upah tenaga kerja, biaya bahan bakar dan lain sebagainya. Penerimaan merupakan hasil produsen dari penjualan produknya. Pendapatan adalah selisih antara penerimaan dengan biaya (Sundari dan Katamso, 2010). Profitabilitas adalah salah satu faktor yang menentukan tinggi rendahnya kinerja usaha. Profitabilitas merupakan perbandingan antara keuntungan dari penjualan dengan biaya total yang dinyatakan dengan persentase (Riyanto, 2001). Tujuan dari penelitian untuk mengetahui besarnya pendapatan dan profitabilitas yang dicapai oleh peternakan sapi perah Gapoktan Sumber Mulya selama 12 bulan.

\section{METODELOGI}

Penelitian dilakukan di peternakan Sapi Perah Sumber Mulya kabupaten Kepahiang provinsi Bengkulu. Peternakan sapi perah Sumber Mulya dipilih sebagai objek penelitian dengan pertimbangan perusahaan sudah bertahan lama lebih dari 10 tahun. Peternakan sapi perah Sumber Mulya adalah salah satu perusahaan terbesar di Kabupaten Kepahiang. Metode penelitian yang digunakan metode studi kasus, yaitu sasaran penelitian yang dapat berupa manusia, peristiwa, latar, dan dokumen, yang ditelaah secara mendalam sebagai suatu totalitas sesuai dengan latar atau konteksnya masing-masing dengan maksud untuk memahami berbagai kaitan yang ada di antara variabel-variabelnya. Metode pengumpulan data yang digunakan adalah dengan pengamatan langsung (observasi) dan wawancara kepada responden Peternakan sapi perah Sumber Mulya dengan panduan kuesioner. Data diperoleh selama 12 bulan terakhir yaitu data bulan 1 Juli tahun 2017 sampai dengan 31 Agustus tahun 2018 mengenai aspek teknis dan keuangan yang meliputi data biaya produksi, data penerimaan, data pendapatan, data jumlah produksi susu dan data jumlah ternak sapi perah laktasi.

Data yang diperoleh dianalisis dengan metode hipotesis diduga usaha peternakan sapi perah Sumber Mulya dengan pendapatan dan profitable. Data dianalisis menggunakan rasio profitabilitas yang digunakan sebagai nilai pembanding dengan suku bunga deposito bank. Rasio profitabilitas menggunakan perbandingan antara pendapatan dan biaya dalam persentase (Riyanto, 2001).

$$
\text { Profitabilitas }=\frac{\text { Pendapatan Bersih }}{\text { Total Biaya Produksi }} \times 100 \%
$$

Keterangan :

1. Jika profitabilitas > tingkat suku bunga deposito bank yang berlaku maka usaha ternak sapi perah menguntungkan.

2. Jika profitabilitas < tingkat suku bunga deposito bank yang berlaku maka usaha ternak sapi perah tidak menguntungkan.

Pendapatan bersih = jumlah penerimaan-Total biaya produksi 


\section{HASIL PENELITIAN}

\section{Gambaran Peternakan Sapi Perah Sumber Mulya}

Peternakan sapi perah Sumber Mulya terletak di desa Sukasari Kecamatan Kabawetan Kabupaten Kepahiang yang berada di ketinggian $\pm 800 \mathrm{~m}$ di atas permukaan laut. Kabupaten Kepahiang merupakan salah satu wilayah di provinsi Bengkulu yang cocok untuk pengembangan sapi perah. Secara georafis kabupaten Kepahiang merupakan daerah pegunungan yang memiliki suhu lingkungan dingin $\left(15-24{ }^{0} \mathrm{C}\right)$ dan memiliki kekayaan alam berupa pakan ternak seperti rumput alam, limbah pertanian, dan limbah industri pertanian yang melimpah untuk pengembangan sapi perah. Pengembangan sapi perah Sumber Mulya dimulai sejak tahun 2008 tepatnya di Gapoktan Sumber Mulya di desa Sukasari kecamatan Kabawetan. Sapi perah merupakan komoditi unggulan yang dikembangkan pemerintah daerah di desa Sukasari tepatnya pada peternakan Sumber Mulya. Tujuan pengembangan sapi perah yang diharapkan berkembang baik dan menguntungkan sehingga dapat dijadikan percontohan pada anggota masyarakat lainnya. Kondisi topografi peternakan sapi perah Sumber Mulya tergolong ideal untuk pemeliharaan ternak sapi perah. Kelembaban udara di peternakan sapi perah Smber Mulya 50-90 $\%$. Perusahaan menempati areal seluas 9.900 meter persegi dengan luas kandang 600 meter persegi. Sisa lahan digunakan untuk bangunan rumah pemilik, ruang produksi susu, ruang pakan, dan bangunan penunjang lainnya.

Peternakan sapi perah Sumber Mulya merupakan suatu perusahaan yang status kepemilikannya perorangan, yang pada awalnya adalah milik Bapak Tarsan Alm. Perusahaan kemudian dipercayakan kepada salah satu menantunya yaitu Bapak Joko Sutrisno untuk melanjutkan usahanya. Peternakan sapi perah Sumber Mulya mendapatkan ijin produksi dari Dinas Peternakan Kabupaten Kepahiang Provinsi Bengkulu. Rataan komposisi ternak peternakan sapi perah Sumber Mulya selama 12 bulan dari bulan Juli 2017 sampai dengan bulan Agustus 2018 tertera pada Tabel 1.

Tabel 1. Rataan komposisi ternak peternakan sapi perah Sumber Mulya dari bulan Juli 2017 sampai dengan bulan Agustus 2018.

\begin{tabular}{ccccc}
\hline Nomor Urut & \multicolumn{2}{c}{ Komposisi Ternak } & Jumlah (ekor) & Persentase (\%) \\
\hline 1 & \multirow{2}{*}{ Pedet } & Jantan & 2 & 10 \\
& & Betina & 5 & 25 \\
2 & \multirow{2}{*}{ Induk } & & & 35 \\
& & Laktasi & 7 & 20 \\
& & Kering & 4 & 10 \\
\hline & & & 2 & 100 \\
\hline
\end{tabular}

Hasil penelitian yang tertera pada Tabel 1. menunjukkan bahwa ternak yang dipelihara oleh peternakan sapi perah Sumber Mulya selama 12 bulan, dari bulan juli 2017 ke bulan 
Agustus 2018 mengalami peningkatan jumlah ternak. Perbandingan sapi perah laktasi dan kering $(63,64 \%$ VS 36,36) memperlihatkan kurang ideal, karena menurut pendapat Makin (2011) yang ideal perbandingan sapi perah sedang laktasi dengan sapi perah kering yaitu 85\%: $15 \%$.

Tabel 2. Rataan produksi susu pada peternakan sapi perah Sumber Mulya dari bulan Juli 2017 sampai bulan Agustus 2018

\begin{tabular}{clr}
\hline No urut & \multicolumn{1}{c}{ Rataan } & \multicolumn{1}{c}{ Total } \\
\hline 1 & Jumlah Sapi Laktasi (ekor) & 7,00 \\
2 & Produksi Susu (liter/bulan) & 1785,00 \\
3 & Prodksi Susu (liter/hari) & 59,50 \\
4 & Produksi Susu (liter/hari/ekor) & 8,50 \\
\hline
\end{tabular}

Hasil pengamatan yang terlihat pada Tabel 2. memperlihatkan produksi susu per hari per ekor sebesar 8,50 liter. Hal tersebut tidak sesuai dengan hasil penelitian Setiyawan et al. (2005) dan Suherman (2013), yang menyatakan bahwa produksi susu sapi perah di Indonesia umumnya masih rendah, yaitu hasil susu rata-rata per ekor per hari adalah 10,50 liter per ekor per hari dengan bangsa ternak Fries Holstein (FH). Namun hasil produksi susu peternakan sapi perah Sumber Mulya masih rendah dibandingkan hasil penelitian Sundari dan Katamso (2010). Rendahnya produksi susu per hari per ekor pada peternakan sapi perah Sumber Mulya diakibatkan pemberian pakan, baik hijauan maupun pakan tambahan (konsentrat) masih kurang dari kebutuhan pakan seekor sapi perah FH, serta ditambah kurang laku hasil produksi susu sehingga masih ada libur susu.

Produksi susu per ekor per hari pada Peternakan sapi perah Sumber Mulya lebih baik jika dibandingkan dengan penelitian yang dilakukan Herawati (2003) menyatakan bahwa produksi susu sapi perah per hari hanya 7,63 liter/ekor. Kadar lemak susu peternakan sapi perah Sumber Mulya sebesar 3,50 dengan berat jenis 1,026. Hal ini sesuai dengan pendapat Soetarno (2000) bahwa kadar lemak susu tidak boleh kurang dari 2,7\%. Perbedaan besarnya kadar lemak dipengaruhi oleh bangsa sapi, sifat keturunan, umur sapi, bulan laktasi, kebuntingan, dan pakan.

\section{Biaya Produksi}

Total biaya produksi merupakan penjumlahan biaya tetap dan biaya variabel selama proses produksi (Suherman, 2006). Lebih jelas total biaya produksi peternakan sapi perah Sumber Mulya tertera pada Tabel 3 berikut ini. 
Tabel 3. Rataan Total biaya produksi peternakan sapi perah Sumber Mulya dari bulan Juli 2017 sampai bulan Agustus 2018

\begin{tabular}{llrr}
\hline Biaya Produksi & Komponen Biaya & Jumlah (Rp) & Persentase (\%) \\
\hline Biaya Tetap & Penyusutan Ternak & $194.641,40$ & 1,91 \\
& Penyusutan Kandang & $8.333,35$ & 0,08 \\
& Penyusutan Kamar & $18.333,50$ & 0,18 \\
& Susu & & \\
& Penyusutan Kantor & $29.166,60$ & 0,29 \\
& Penyusutan Kendaraan & $58.333,50$ & 0,59 \\
& Penyusutan Peralatan & $52.732,44$ & 0,53 \\
& Gaji Pegawai & $1.900 .000,00$ & 18,94 \\
& Sewa tanah & $20.000,00$ & 0,19 \\
\hline Total Biaya Tetap & & $2.281 .540,79$ & \\
\hline Biaya Tidak Tetap & & 56,62 \\
& Pakan & $5.680 .208,00$ & 2,84 \\
& Perbaikan & $284.444,00$ & 1,25 \\
& Kesehatan Hewan dan & $125.694,00$ & 1,79 \\
& IB & & 6,52 \\
& Kemasan & $180.092,50$ & 1,09 \\
& Bahan Bakar & $653.872,00$ & 4,99 \\
& Listrik dan Telepon & 109000,00 & 2,17 \\
\hline Loper Susu & $500.500,00$ & \\
Lain-lain & $217.472,00$ & 100,00 \\
\hline Total Biaya Tidak Tetap & $7.751 .282,50$ & \\
\hline Total Biaya Produksi & $10.032 .823,29$ & \\
\hline
\end{tabular}

Tabel 3. menunjukkan besarnya rataan biaya produksi pada perusahaan susu sapi perah Sumber Mulya selama 12 bulan yang terhitung dari bulan Juli tahun 2017 sampai dengan bulan Agustus tahun 2018. Perhitungan rataan biaya produksi dari bulan Juli tahun 2017 sampai dengan bulan Agustus tahun 2018 terus mengalami peningkatan. Rataan biaya produksi yang terbesar adalah biaya pakan sebesar $56,62 \%$ dan gaji pegawai sebesar 18,94\%. Hal ini sesuai dengan pendapat Hadiwidjaya dan Lely. (2009) bahwa biaya pakan merupakan biaya terbesar dari keseluruhan biaya produksi. Listrik dan telepon merupakan sarana penting dalam perusahaan karena telepon merupakan sarana komunikasi untuk memperlancar kegiatan perusahaan dalam memasarkan susu, seran gaji tidak tetap merupakan biaya tidak tetap yang dikeluarkan oleh perusahaan. Komisi loper susu diberikan berdasarkan berapa banyak loper tersebut berhasil menjual susu kepada konsumen, semakin banyak loper tersebut berhasil menjual susu kepada konsumen maka komisi yang didapat juga akan semakin banyak.

\section{Penerimaan}

Rataan besarnya penerimaan peternakan sapi perah Sumber Mulya per bulan dari penjualan susu dan penjualan pedet yang tertera pada Tabel 4 . 
Tabel 4. Rataan penerimaan dari penjualan susu peternakan sapi perah Sumber Mulya dari bulan Juli 2017 sampai dengan bulan Agustus 2018

\begin{tabular}{clcccc}
\hline No & \multicolumn{1}{c}{$\begin{array}{c}\text { Sumber } \\
\text { Penerimaan }\end{array}$} & $\begin{array}{c}\text { Jumlah Produksi } \\
(\text { liter })\end{array}$ & $\begin{array}{c}\text { Jumlah } \\
\text { Pedet } \\
(\text { ekor })\end{array}$ & $\begin{array}{c}\text { Penerimaan } \\
(\mathrm{Rp})\end{array}$ & $\begin{array}{c}\text { Persentase } \\
(\%)\end{array}$ \\
\hline \multirow{2}{*}{$\begin{array}{l}\text { Penjualan Susu } \\
2\end{array}$} & Loper & 500,00 & & $4.000 .000,00$ & 25,87 \\
& Konsumen & 280,00 & & $960.000,00$ & 12,68 \\
3 & Langsng & & & & 35,58 \\
& Koperasi & 1000,00 & & $5.500 .000,00$ & \\
4 & Penjualan pedet & & 2,00 & $.000 .000,00$ & 25,87 \\
\hline Total Penerimaan & 1780,00 & 2,00 & $5.460 .000,00$ & 100,00 \\
\hline
\end{tabular}

Hasil penelitian yang tersaji pada Tabel 4. menunjukkan besarnya rataan peneriamaan peternakan sapi perah Sumber Mulya dari penjualan susu dan penjualan pedet. Rataan Penerimaan tergantung pada jumlah susu yang dijual melalui loper, konsumen langsung yang membeli susu, dan dijual ke koperasi. Penjualan susu terbesar dilakukan oleh koperasi. Koperasi menjual 56,18\% total susu yang ada, sedangkan ke loper $28,09 \%$ dan sisanya susu yang dijual secara langsung ke kosumen 15,73\%. Penerimaan peternakan sapi perah Sumber Mulya beasal dari penjualan susu dan pedet. Rataan penerimaan dari penjualan susu terbesar berasal dari koperasi sebesar Rp.5.500.000,00 perbulan, serta rataan penerimaan perusahan dari penualan pedet sebesar Rp. 4.000.000,00 perbulan. Harga susu yang dijual perusahaan pada koperasi adalah Rp. 5.500,00 perliter susu, pada loper dijual seharga Rp. 8.000,00 perliter susu, dan pada konsumen Rp. 7.000,00 perliter susu. Susu yang dijual ke konsumen secara langsung merupakan sisa dari penjualan. Hal tersebut merupakan cara yang dilakukan peternakan sapi perah Sumber Mulya untuk mempengaruhi kerugiaan.

\section{Pendapatan atau Profit}

Keuntungan atau profit merupakan selisih antara penerimaan dan besarnya biaya produksi. Pendapatan peternakan sapi perah Sumber Mulya yang tertera pada Tabel 5.

Tabel 5. Rataan pendapatan per bulan peternakan sapi perah Sumber Mulya dari bulan Juli 2017 sampai bulan Agustus 2018

\begin{tabular}{clr}
\hline No Urut & \multicolumn{1}{c}{ Komponen } & Jumlah Rataan \\
\hline 1 & Total Penerimaan (rupiah) $(\mathrm{A})$ & $15.460 .000,00$ \\
2 & Total Biaya (rupiah) (B) & $10.032 .823,29$ \\
3 & Pendapatan/Profit (rupiah) $(\mathrm{A}-\mathrm{B})=(\mathrm{C})$ & $5.427 .176,71$ \\
4 & Dikonsumsi Keluarga (rupiah) (D) & $30.000,00$ \\
\hline 5 & Profitabilitas (\%) (C -D/B*100\% & 53,79 \\
\hline
\end{tabular}

Tabel 5. Menunjukkan bahwa rataan pendapatan atau profit (keuntungan) peternakan sapi perah Sumbert Mulya per bulan sebesar Rp. 5.427.176,91 dan susu yang dikonsumsi keluarga sebanyak 5 liter/bulan dengan asumsi harga susu sebesar Rp. 6.000,00. 


\section{Analisis Rasio Profitabilitas}

Hasil perhitungan yang tertera pada Tabel 5. menunjukkan bahwa besarnya nilai rataan profitabilitas pada peternakan sapi perah Sumber Mulya sebesar (53,79\%). Nilai profitabilitas $53,79 \%$ lebih besar dari tingkat suku bunga deposito, baik BRI maupun BNI dan Mandiri periode Agustus 2018 yaitu sebesar 9,00\%. Suku bunga yang digunakan dalam analisis ini bukan suku bunga kredit melainkan suku bunga deposito bank dikarenakan perusahaan menggunakan modal sendiri dalam usahanya. Berdasarkan uji nilai sig (0.000) bahwa nilai profitabilitas perusahaan berbeda sangat nyata dengan nilai suku bunga deposito bank yang berlaku, sehingga peternakan sapi perah Smber Mulya ini profitable, hal ini sesuai hasil penelitian Hadiwidjaya et al. (2009) dan Sundari dan Katamso (2010) serta Wardani et al. (2012) bahwa semakin besar tingkat keuntungan menunjukan semakin baik manajemen dalam mengelola perusahaan.

\section{KESIMPULAN}

Berdasarkan hasil penelitian yag telah dilaksanakan dapat diambil kesimpulan bahwa pendapatan bersih yang dicapai peternakan sapi perah Sumber Mulya rataan per bulan sebesar Rp. 5.427.176,91 dengan jumlah sapi laktasi rataan sebanyak 7 ekor. Total biaya yang dikeluarkan per bulan sebesar Rp. 10.032.823,29. Profitabilitas yang dicapai sebesar 53,79\%, perusahaan dikatakan profitable karena nilai profitabilitas lebih besar dari suku bunga bank sebesar $9,00 \%$.

\section{DAFTAR PUSTAKA}

Badan Pusat Statistik (BPS). 2018. Bengkulu dalam angka 2018. Bengkulu.

Hadiwidjaya, R.D. dan F.T.Lely. 2009. Pengaruh profitabilitas terhadap dividend payout ratio pada perusahaan manufaktur di Indonesia. Jurnal Organisasi dan Manajemen. Vol : 5. Nomor 2. 49-54.

Hadiwiyoto, S. 1994. Teori dan Prosedur Pengujian Mutu Susu dan Hasil Olahannya. Edisi II. Liberty. Yogyakarta.

Herawati. 2003. Pengaruh subtitusi hijauan pakan dalam ransum dengan nanas afkir terhadap produksi dan kualitas susu pada sapi perah laktasi. J.Indon.Trop.Anim.Agric.Vol : 28. Nomer 2. $56-63$.

Kediri. Animaql Agricultural Jornal 1(1): 339 -357.

Makin M. 2011. Tatalaksana peternakan sapi perah. Graha Ilmu.Jogyakarta.

Rasyaf. 1996. Memasarkan hasil ternak. Penebar Swadaya. Jakarta.

Riyanto, R. 2001. Dasar Tabel 5. Menunjukkan bahwa rataan pendapatan atau profit (keuntungan) peternakan sapi perah Sumbert Mulya per bulan sebesar Rp. 5.427.176,91 dan susu yang dikonsumsi keluarga sebanyak 5 liter/bulan dengan asumsi harga susu sebesar Rp. 6.000,00.dasar pembelanjaan perusahaan. Penerbit BPFE. Yogyakarta. 
Setiyawan H, S.I Santoso, Mukson. 2005. Analisis finansial usaha peternakaqn sapi perah pada tingkat perusahaann. Animal Production Journal 7 (1) : 40 - 45.

Soekartawi. 1993. Prinsip dasar ekonomi pertanian. PT Raa Grafinda Persada. Jakarta.

Soetarno Y. 2000. Ilmu produksi ternaqk perah. Universitas Gadjahmada. Yogyakarta.

Sudono, A. 2004. Beternak sapi perah secara intensif.Agromedia Pustaka. Jakarta.

Suherman, D. 2006. Pendapatan dan pencurahan tenaga kerja keluarga pada berbagai skala usaha peternakan sapi potong rakyat di kecamatan Sukaraja Bengkulu Selatan. Jurnal Sain Peternakan Indonesia 1 (2) : 26 - 31.

Suherman D, B.P. Purwanto, I.G. Permana, W. Manalu. 2013. Penentan suhu kritis atas pada sapi dara Fries Holstein berdasarkan respon fisiologis dan manajemen pakan melali Artificial neural network. Disertasi. Pasca sarjana Institut Pertanian Bogor. Bogor.

Sundari dan Katamso. 2010. Analisis pendapatan peternak sapi perah lokal dan eks impor anggota koperasi warga Mulya di Kabupaten Sleman Yogyakarta. J. Caraka Tani XXV no : $1: 26-32$

Sutrisno. 2000. Manajemen Keuangan. Penerbit Ekonosia. Yogyakarta.

Wardani TC, K Bdiharjo, E Prasetyo. 2012. Analisis profitabilitas pada peternakan sapi perah "Karunia" 